(c) American Dairy Science Association, 2006.

\title{
A Systems Comparison of Once- Versus Twice-Daily Milking of Pastured Dairy Cows
}

\author{
D. A. Clark, ${ }^{1}$ C. V. C. Phyn, M. J. Tong, S. J. Collis, and D. E. Dalley \\ Dexcel, Private Bag 3221, Hamilton, New Zealand
}

\section{ABSTRACT}

The objective of this study was to compare the effect of milking frequency (once vs. twice-daily milking) and breed (Holstein-Friesians vs. Jerseys) on milk and milk solids (MS; milk fat + milk protein), yield per cow, milk composition, somatic cell count and lactation length; cow body weight, body condition score, and reproductive performance over a 4 -yr period. Total cow numbers in each herd were 30, 35, 36, and 42 for Holstein-Friesians milked once or twice daily, and Jerseys milked once or twice daily, respectively. Forty hectares of pasture were subdivided into 4 smaller pastures of 10 ha each. Stocking rates for the once-daily herds were $16.7 \%$ greater than the twice-daily herd in their respective breed. An increased stocking rate was chosen to achieve equal milk and MS per ha from the 2 milking frequencies. Annual milk, fat, protein, and lactose yields per cow were less for once-daily than for twice-daily milking. Interactions were detected between milking frequency and breed for annual milk, fat, protein, and lactose yields per cow, because Jerseys were relatively less affected by once-daily than by twice-daily milking than Holstein-Friesians. Holstein-Friesian cows milked once daily produced $31.2 \%$ less milk and $29.4 \%$ less MS per cow than their twice-daily counterparts. In contrast, Jersey cows milked once daily produced $22.1 \%$ less milk and $19.9 \%$ less MS per cow than their twice-daily counterparts. Milk per ha was 17.7 and 9\% less for the oncedaily Holstein-Friesians and once-daily Jersey herds, respectively, compared with their twice-daily counterparts, because the greater stocking rate for the oncedaily herds did not fully compensate for the milk loss per cow. Milking once daily increased somatic cell count throughout the year in both breeds. Cows milked once daily conceived $3 \mathrm{~d}$ earlier, took $5 \mathrm{~d}$ less from calving to conception, and needed $11 \%$ fewer controlled internal drug release devices than those milked twice daily. Milking once daily is a viable milking option for New Zealand farmers who are prepared to trade-off loss of

Received April 14, 2005.

Accepted November 28, 2005.

${ }^{1}$ Corresponding author: dave.clark@dexcel.co.nz
MS income for increased time to accomplish other nonmilking activities.

Key words: milking frequency, pasture, breed, grazing

\section{INTRODUCTION}

The New Zealand dairy industry is driven by seasonal-calving and pasture-based farm systems with low, unsubsidized milk prices, low per-cow milk yield by international standards, an average herd size of 300 cows, difficulty in employing suitable staff, and a demand from employers and staff for a better lifestyle. New Zealand dairy farmers traditionally have accepted twice-daily milking as the standard frequency of milk removal. Increasingly, this convention is being challenged as dairy farmers strive to improve their profitability and lifestyle. Although many different ways of achieving this objective exist, once-daily milking provides a major opportunity to reduce farm costs. Potential benefits from once-daily milking include increased labor productivity, reduced milking parlor expenses, and improved lifestyle for farming families and staff.

Losses in milk yield from once-daily milking have been reported to range from 7 to $38 \%$ in part-lactation trials (Davis et al., 1999), in which control cows milked twice daily were typically producing 15 to $20 \mathrm{~kg}$ of milk per day (Parker, 1965; Wilson, 1965; Bryant, 1978; Mackenzie et al., 1990; Morris et al., 1991). Milk production loss tended to be less in late lactation in absolute and percentage terms (Carruthers and Copeman, 1990; Carruthers et al., 1993). Wide variation exists among individual cows in the degree of milk production loss (3 to $47 \%$ ) when switched from twice-daily to once-daily milking (Carruthers and Copeman, 1990; Carruthers et al., 1993). First-lactation cows may show substantial losses under once-daily milking (Attrill and Holmes, 1993). Nevertheless, there is evidence to indicate that a significant proportion of cows show minimal yield losses when milked once daily, suggesting the possibility of selecting cows that tolerate less frequent milking (Woolford et al., 1982).

Few full-lactation studies exist comparing once-daily with twice-daily milking. Claesson et al. (1959) reported a production loss of $50 \%$ in the first lactation and $40 \%$ in the second lactation for once-daily compared with 
twice-daily milking. In a New Zealand study, Holmes et al. (1992) reported a production loss of $35 \%$ to oncedaily milking. There were no first-lactation cows in their study, however, which may account for some of the difference between the two studies. In high-yielding cows, Rémond et al. (2004) reported 30\% less milk from cows milked once daily compared with those milked twice daily during an entire lactation.

Strategies to overcome milk production losses must be found if once-daily milking is to be economically viable. Jersey cows may have an advantage for oncedaily milking as they can accumulate milk for greater than $24 \mathrm{~h}$, mainly because of relatively concentrated milk, high in fat and protein content (Carruthers et al., 1993). American Holsteins may be less suited to oncedaily milking because they produce less concentrated milk and their udders can only accumulate 19 -h worth of milk secretions (Davis et al., 1998).

Cows milked once daily throughout lactation have a reduced DMI and more BW than those milked twice daily (Holmes et al., 1992). Rémond et al. (2004) found no difference in DMI between once- and twice-daily milked cows during the first $14 \mathrm{wk}$ of lactation, but once-daily cows had smaller DMI than twice-daily cows during the remainder of lactation. Therefore, an increased stocking rate (cows/ha) under once-daily milking may maintain efficient pasture use and overcome the reduction in whole farm milk and milk solids (MS) production.

The objective of the current study was to compare the effect of milking frequency (once vs. twice daily), and breed (Holstein-Friesians vs. Jerseys) on milk and MS yield per cow, milk composition, SCC, lactation length, BW, BCS, and reproductive performance. Cows grazed self-contained pastures. These pastures were designed to reduce the effect of once-daily milking on milk and MS yield per ha by using greater stocking rates for the once-daily compared with twice-daily milked herds.

\section{MATERIALS AND METHODS}

\section{Cows}

Forty-nine Holstein-Friesian cows and 16 heifers, and 58 Jersey cows and 20 heifers were allocated randomly to 2 herds per breed balanced for age, calving date, BW, BCS, genetic merit, and MS yield in their previous lactation (multiparous cows) on June 1, 2000. Total cows in each herd were 35 and 30 , respectively, for Holstein-Friesians milked once or twice daily and, 36 , and 42, respectively, for Jerseys milked once or twice daily. Thus, 4 breed-milking frequency treatment combinations were created. All cows were expected to remain in their respective herds for $4 \mathrm{yr}$ unless culled.
Annual replacement rate was set at approximately $20 \%$, and culled animals were replaced with 2 -yr herd replacements randomly allocated to treatments. The Ruakura Animal Ethics Committee approved all procedures involving dairy cows used in this study.

\section{Cow Allocation and Measurements}

Cows were milked at approximately $0600 \mathrm{~h}$ (once daily and twice daily) and $1600 \mathrm{~h}$ (twice daily only). Milk yields in 2000-2001 were recorded from biweekly (every other week) herd tests of individual cows using p.m./a.m. sampling for twice-daily and a.m. sampling for once-daily herds. During the final $3 \mathrm{yr}$, individual milk yields were recorded at each milking. Individual cow milk composition (fat, protein, and lactose) was measured on composite milk samples from the p.m./ a.m. milkings for the twice-daily herds and on a single a.m. sample for the once-daily herds at 2-wk intervals during each lactation. A Milkoscan 133B milk analyzer (Foss Electric, Hillerød, Denmark), calibrated for different matrix effects for milk from the different breeds was used. The SCC for individual cows was measured every 2 wk using a cell counter (Fossomatic, Foss Electric). Quarter foremilk samples were collected aseptically from all cows at calving, midlactation, and at dry-off for detailed bacteriological analysis, and for all cows showing signs of clinical mastitis before they received treatment (Lacy-Hulbert et al., 2005). The latter results for bacteriology and the number of mastitic infections for each treatment were reported previously (Lacy-Hulbert et al., 2005).

The BCS on a 1-to-10 scale (Roche et al., 2004) and BW were measured every 2 wk for each cow after the morning milking from calving until drying-off and then at monthly intervals.

Detailed breeding records were kept for each cow, including the dates of prebreeding heats, each breeding, subsequent heats, any hormonal treatments, and the results of pregnancy tests. Each year data were used to calculate intervals from calving to first estrus, calving to conception, submission rate, conception rate to first breeding, inseminations per conception, and pregnancy rate.

\section{Pasture Design}

The trial started June 1, 2000, at the Westpac Taranaki Agricultural Research Station near Normanby, New Zealand on Egmont brown loam soils. On June 1, 2001, the Normanby site became unavailable and the cows were relocated $15 \mathrm{~km}$ to a new site at Whareroa on Egmont black loam soils, on which the final $3 \mathrm{yr}$ of the trial were completed on May 31, 2004. Forty hectares of 
perennial ryegrass (Lolium perenne L.) and white clover (Trifolium repens L.) pasture at each site were subdivided into 4 pastures of 10 ha each. Pastures at both sites were in several noncontiguous blocks; equal areas within each block were allocated randomly to the 4 treatment combinations to achieve balanced topography, soil fertility, and distance from the farm dairy for each treatment. Stocking rate for the once-daily herd was set $16.7 \%$ greater than their counterpart breed herd milked twice daily. This increased stocking rate was chosen to try to achieve equal milk and MS per ha relative to the 2 milking frequencies, because previous research had shown that once-daily milking would reduce milk production by 7 to $28 \%$ for part-lactation studies when cows produced 8 to $18 \mathrm{~kg}$ of milk/d (Davis et al., 1999). It was expected that DMI also would be reduced (Holmes et al., 1992). The stocking rate difference between breeds was chosen to give a similar BW per ha for each herd. Pastures and herds could not be replicated because of lack of resources, but there was replication across both years and sites.

\section{Pasture Management}

Pastures were operated under standard decision rules (Macdonald and Penno, 1998) to ensure consistency in grazing management, conservation, supplementation, drying off, and culling. Culling decisions during the experiment represented those practiced on New Zealand seasonal dairy farms. All cows that failed, or were late, to conceive were culled. This was the major reason for culling, as it is on commercial New Zealand dairy farms (Xu and Burton, 2000). The targeted 20\% replacement rate meant that herds with high culling rates for reproduction failure had fewer cows available for culling for other purposes.

All cows calved in spring (southern hemisphere) with planned start of calving on July 20 each year. At planned start of breeding, noncycling cows were treated with controlled internal drug release devices (CIDR; InterAg, Hamilton, New Zealand; Macmillan et al., 1991) conatining $1.9 \mathrm{~g}$ of progesterone. At calving, colostrum was withheld from the bulk tank for 4 or $5 \mathrm{~d}$ from older cows and first-lactation cows, respectively. Cows allocated to once-daily treatments were milked once daily from the first day after calving.

\section{Statistical Analyses}

Milk yield and MS yield/ha were calculated for each herd for each year. Reproductive measurements also were obtained for each herd during each of the $4 \mathrm{yr}$. These data were analyzed using ANOVA of the 16 herd means with year, breed, milking frequency, and breed $x$ frequency interaction as fixed effects and the year $x$ herd interaction as the error term.

Body weight and BCS for individual cows at 2 stages of lactation (8 and $38 \mathrm{wk}$ after planned start of calving) each year were used to test for treatment differences. Annual milk yield, fat, protein, and lactose contents were calculated for each cow per year. Mean $\log _{10} \mathrm{SCC}$ was calculated for each cow per year. Transformation of SCC data was necessary to meet the assumptions of the statistical test used, and to provide valid treatment comparisons. The untransformed SCC bulk milk from each herd was calculated from an annual mean SCC for each cow from biweekly herd test milk yield and SCC, weighting by milk yield, and then calculating herd means from these weighted averages. Estimated bulk milk SCC for each treatment gave a clearer indication of the bulk milk SCC that would be sent to the processor.

The $4 \mathrm{yr}$ of annual BW, BCS, SCC, milk yield, and milk composition ( $143 \times 4$ total observations) were analyzed as a mixed model using REML with year, breed, milking frequency, and breed $\times$ milking frequency as fixed effects, and year $\times$ herd interaction and cow as random effects. All means presented in tables were obtained from REML analysis. Effect of age $(2,3$, or $>4$ yr old cows) was determined using REML and a model including year, breed, milking frequency, age, and firstorder interactions as fixed effects, and cow as a random effect. Effect of lactation number during the experiment (1, 2, 3, or 4 lactations) was determined by including number of lactations and first-order interactions in this model. This was necessary because of the confounding of year, age, and number of lactations. All statistical analyses were carried out using GenStat 7.1 (VSN Int. Ltd., Herts, UK).

\section{RESULTS}

\section{Milk Volume and Composition}

Mean annual yields of milk, fat, protein, and lactose per cow are presented in Table 1, and milk and MS/ ha in Table 2. Significant interactions were detected between milking frequency and breed for all yield measures. Annual milk, MS, fat, protein, and lactose yields per cow were less $(P \leq 0.05)$ for once-daily compared with twice-daily milking in both Jerseys and HolsteinFriesians (Table 1). Holstein-Friesians milked once daily, however, had greater yield losses per cow compared with Jerseys milked once daily in both absolute and relative terms. Increased stocking rate for oncedaily herds compared with twice-daily herds reduced $(P \leq 0.05)$ the extent of the milk production loss per ha. Holstein-Friesian cows milked once daily produced 29.4 and $16.4 \%$ less $(P \leq 0.05)$ MS per cow and per ha than their twice-daily counterparts, whereas Jersey cows 
Table 1. Predicted annual milk, milk protein, fat, and lactose yields for Holstein-Friesian (HF) and Jersey $(J)$ cows milked once $(1 \times)$ or twice $(2 \times)$ daily for $4 \mathrm{yr}$

\begin{tabular}{|c|c|c|c|c|c|c|c|c|}
\hline & \multicolumn{4}{|c|}{ Breed-daily milking frequency } & \multirow[b]{2}{*}{$\mathrm{SED}^{1}$} & \multicolumn{3}{|c|}{$P$-value } \\
\hline & $\mathrm{HF}-1 \times$ & $\mathrm{HF}-2 \times$ & $J-1 \times$ & $J-2 \times$ & & Breed & Frequency & Interaction \\
\hline Milk yield, kg/cow & 2,914 & 4,234 & 2,211 & 2,839 & 195.4 & $<0.001$ & $<0.001$ & 0.02 \\
\hline Fat yield, kg/cow & 130.8 & 186.7 & 128.9 & 161.8 & 7.51 & 0.029 & $<0.001$ & 0.035 \\
\hline Protein yield, kg/cow & 106.2 & 149.1 & 93.5 & 115.8 & 6.29 & $<0.001$ & $<0.001$ & 0.028 \\
\hline Lactose yield, $\mathrm{kg} / \mathrm{cow}$ & 137.5 & 205.2 & 106.6 & 140.5 & 8.99 & $<0.001$ & $<0.001$ & 0.015 \\
\hline
\end{tabular}

${ }^{1}$ Standard error of the difference between treatment means.

milked once daily produced only 19.9 and $6.3 \%$ less $(P$ $\leq 0.05)$ MS per cow and per ha than their twice daily counterparts, implying that Jerseys were less affected by once-daily milking. Lactation length was $14 \mathrm{~d}$ shorter $(P \leq 0.05)$ for once-daily compared with twicedaily milking, but no breed effect or interaction of breed with milking frequency was detected (Table 2).

Milk protein concentration and SCC were greater $(P \leq$ $0.05)$ for once-daily compared with twice-daily milking, and milk lactose concentration was less $(P \leq 0.05$; Table $3)$. Fat concentration showed a tendency $(P=0.097)$ to increase by $0.10 \%$ under once-daily milking. No breed effect on SCC was detected. No milking frequency $x$ breed interactions were detected for any of the milk components or SCC. The estimated bulk milk SCC in all treatments were less than the penalty threshold of 400,000 cells/mL for New Zealand, but both once-daily treatments were consistently greater than those milked twice daily.

\section{Lactation Number and Milk Production}

Predicted means for MS yield per cow of 3 ages for each treatment are given in Table 4 . A tendency $(P=$ 0.082 ) was detected for a breed $\times$ milking frequency $\times$ age interaction for MS per cow. The 2- and 3-yr-old Holstein-Friesians had a greater production drop under once-daily milking than cows aged 4 or more years (39 and $36 \%$ vs. $25 \%$ less MS per cow, respectively). In contrast, 2- and 3-yr-old Jerseys had similar production losses under once-daily milking compared with 4+ yrold Jerseys ( 24 and $16 \%$ vs. $19 \%$ less MS per cow, respectively).
No evidence of a milking frequency $\times$ number of lactations interaction was detected, indicating that cows did not adapt to once-daily milking over several lactations, nor were they disadvantaged by being milked once daily in previous lactations. These results must be interpreted with caution because of the confounding effect of age and number of lactations on the trial. Obviously, first-lactation cows cannot have a previous history of once-daily milking, and also the nature of the trial design means that age and number of lactations on trial are confounded.

\section{$B C S$ and $B W$}

Cows milked once daily had greater BCS after calving by 0.34 units (BCS on a 1-to-10 scale; Roche et al., 2004) than those milked twice daily (Table 5), but no effect of milking frequency on BW was detected at this stage of lactation. Both breeds had similar BCS postcalving despite Holstein-Friesians being $105 \mathrm{~kg}$ heavier than the Jerseys. At dry-off, cows milked once daily had added $58 \mathrm{~kg}$ of BW compared with $43 \mathrm{~kg}$ for the twicedaily cows. At dry-off, both Holstein-Friesians and Jerseys milked twice daily had the same BCS, but oncedaily Holstein-Friesians had BCS 0.5 units greater than once-daily milked Jerseys, resulting in a breed $\times$ milking frequency interaction.

\section{Reproductive Performance}

Cows milked once daily had greater 3 -wk submission rates $(+7.3 \% ; P=0.01)$ and 3 -wk pregnancy rates $(+7.8 \% ; P=0.055)$ than those milked twice daily (Table

Table 2. Predicted mean annual milk and milk solids (MS) (fat + protein) yield per ha and lactation length for Holstein-Friesian (HF) and Jersey (J) cows milked once $(1 \times)$ or twice $(2 \times)$ daily for $4 \mathrm{yr}$

\begin{tabular}{|c|c|c|c|c|c|c|c|c|}
\hline & \multicolumn{4}{|c|}{ Breed-daily milking frequency } & \multirow[b]{2}{*}{$\mathrm{SED}^{1}$} & \multicolumn{3}{|c|}{$P$-value } \\
\hline & HF- $1 \times$ & $\mathrm{HF}-2 \times$ & $\mathrm{J}-1 \times$ & $\mathrm{J}-2 \times$ & & Breed & Frequency & Interaction \\
\hline Milk yield, kg/ha & 10,914 & 13,262 & 9,699 & 10,652 & 338.2 & $<0.001$ & $<0.001$ & 0.017 \\
\hline Milk solids yield, $\mathrm{kg} / \mathrm{ha}$ & 879.3 & $1,050.8$ & 979.4 & $1,044.8$ & 20.17 & 0.009 & $<0.001$ & 0.005 \\
\hline Lactation length, $d$ & 230 & 244 & 229 & 242 & 7.0 & 0.77 & 0.009 & 0.99 \\
\hline
\end{tabular}

${ }^{1}$ Standard error of the difference between treatment means. 
Table 3. Predicted annual milk protein, fat, and lactose content and $\log _{10}$-transformed SCC (log SCC, $\times 1,000$ cells $\left./ \mathrm{mL}\right)$ for Holstein-Friesian $(\mathrm{HF})$ and Jersey $(\mathrm{J})$ cows milked once $(1 \times)$ or twice $(2 \times)$ daily for $4 \mathrm{yr}$

\begin{tabular}{|c|c|c|c|c|c|c|c|c|}
\hline & \multicolumn{4}{|c|}{ Breed-daily milking frequency } & \multirow[b]{2}{*}{$\mathrm{SED}^{1}$} & \multicolumn{3}{|c|}{$P$-value } \\
\hline & HF-1× & $\mathrm{HF}-2 \times$ & $\mathrm{J}-1 \times$ & $\mathrm{J}-2 \times$ & & Breed & Frequency & Interaction \\
\hline Milk fat, $\%$ & 4.48 & 4.42 & 5.83 & 5.67 & 0.099 & $<0.001$ & 0.097 & 0.45 \\
\hline Milk protein, \% & 3.64 & 3.52 & 4.22 & 4.06 & 0.048 & $<0.001$ & $<0.001$ & 0.54 \\
\hline Milk lactose, \% & 4.70 & 4.84 & 4.81 & 4.94 & 0.030 & $<0.001$ & $<0.001$ & 0.68 \\
\hline $\log _{10} \mathrm{SCC}$ & 2.21 & 1.87 & 2.19 & 1.92 & 0.059 & 0.82 & $<0.001$ & 0.46 \\
\hline Bulk milk SCC, ${ }^{2}(\times 1,000$ cells $/ \mathrm{mL})$ & 298 & 160 & 248 & 175 & $\mathrm{NA}^{3}$ & $\mathrm{NA}$ & NA & NA \\
\hline
\end{tabular}

${ }^{1}$ Standard error of the difference between treatment means.

${ }^{2}$ Mean annual bulk milk SCC was calculated from a weighted mean for each cow, based on biweekly (every other week) herd test milk yield and SCC, and then treatment means were calculated.

${ }^{3} \mathrm{NA}=$ Not applicable.

6). No effect of milking frequency was detected for 3-wk conception rate, 6-wk $\mathrm{AI}$ submission rate, conception, or pregnancy rates, days to first estrus, or total number of inseminations per cow. Cows milked once daily conceived $3 \mathrm{~d}$ earlier, required $5 \mathrm{~d}$ less from calving to conception, and $11 \%$ fewer CIDR inserts were applied than those milked twice daily.

Jerseys had a $7.7 \%$ greater 3 -wk submission rate than Holstein-Friesians. Use of CIDR inserts was 6.7\% less for the Jerseys than the Holstein-Friesians, but a milking frequency $\times$ breed interaction was detected, with CIDR use being much greater for the twice-daily Holstein-Friesians cows than for the other treatment combinations. A milking frequency $\times$ breed interaction was not detected for any other reproductive measures.

\section{DISCUSSION}

\section{Milk Yield}

A direct comparison of milk yield per cow from our experiment and others on once-daily milking is difficult because we have different stocking rates in the 2 systems. Many cows had more than one lactation on oncedaily milking and we used a combination of primiparous and multiparous cows. In the current study, annual

Table 4. Predicted annual milk solids yield $(\mathrm{kg} / \mathrm{cow})^{1}$ for different ages of Holstein-Friesian (HF) and Jersey $(J)$ cows milked once (1×) or twice $(2 \times)$ daily for $4 \mathrm{yr}$

\begin{tabular}{lllll}
\hline & \multicolumn{4}{c}{ Breed-daily milking frequency ${ }^{2}$} \\
\cline { 2 - 5 } Age, yr & HF-1× & HF-2× & J-1× & J-2× \\
\hline 2 & 173.5 & 280.2 & 172.8 & 227.1 \\
3 & 220.9 & 344.6 & 224.3 & 266.6 \\
$4+$ & 271.4 & 361.9 & 247.0 & 306.3 \\
\hline
\end{tabular}

${ }^{1}$ Average standard error of difference was $13.0 \mathrm{~kg}$ of milk solids per cow (4-yr average).

${ }^{2}$ Frequency $\times$ age interaction $(P=0.89)$; frequency $\times$ lactation number $(P=0.86)$; and frequency $\times$ age $\times$ breed interaction $(P=0.082)$. milk yield for $4 \mathrm{yr}$ for once-daily Holstein-Friesians was 27.5 to $32.2 \%$ less than that for twice-daily HolsteinFriesians. Yield for once-daily Jerseys was 16.6 to $25.4 \%$ less than for twice-daily Jerseys. These are smaller losses than reported for another grazing, wholelactation study using Holstein-Friesians and Jerseys (Holmes et al., 1992); but greater than the $8 \%$ loss calculated by Woolford et al. (1985) for a herd consisting of $24 \%$ heifers milked 3 times every $2 \mathrm{~d}$. During an entire lactation study, cows milked once daily recorded a $30 \%$ decrease in milk yield $(5,114 \mathrm{~kg})$ compared with those milked twice daily (7,323 kg; Rémond et al., 2004). Davis et al. (1999) reviewed once-daily milking experiments and found that the once-daily milk yield loss, expressed as a percentage of milk yield from twice-daily controls, increased with the duration of once-daily milking.

The current work shows that Jerseys have a smaller loss from once-daily milking than Holstein-Friesians. Carruthers et al. (1993) reported a 12-wk trial during early lactation comparing high-protein Jerseys, lowprotein Jerseys, and Friesians, in which losses in milk yield were 10,20, and $27 \%$ for the 3 groups, respectively. High-protein Jerseys, but not the low-protein Jerseys had smaller losses than the Friesians, with no difference between Jerseys. They found that Jerseys had less udder involution on once-daily milking than the Friesians. In the current study, the $16.7 \%$ increase in stocking rate (cows/ha) for once-daily Holstein-Friesian and once-daily Jersey herds was unable to overcome the deficit in milk or MS yield per cow incurred under once-daily milking to allow equal MS per ha for the 2 milking frequencies. Woolford et al. (1985) suggested the possibility of increasing stocking rate for cows milked on a 16-h cycle to achieve similar milk yield per ha. Milking once daily for only the latter part of lactation also would likely substantially reduce the loss of milk yield compared with twice-daily milking. 
Table 5. Predicted postcalving and drying off BW and BCS for Holstein-Friesian (HF) and Jersey (J) cows milked once $(1 \times)$ or twice $(2 \times)$ daily (4-yr average)

\begin{tabular}{|c|c|c|c|c|c|c|c|c|}
\hline & \multicolumn{4}{|c|}{ Breed-daily milking frequency } & \multirow[b]{2}{*}{$\mathrm{SED}^{1}$} & \multicolumn{3}{|c|}{$P$-value } \\
\hline & $\mathrm{HF}-1 \times$ & $\mathrm{HF}-2 \times$ & $J-1 \times$ & $J-2 \times$ & & Breed & Frequency & Interaction \\
\hline Postcalving BW, kg & 474.7 & 457.7 & 363.4 & 359.7 & 12.35 & $<0.001$ & 0.25 & 0.45 \\
\hline Postcalving $\mathrm{BCS}^{2}$ & 5.05 & 4.65 & 4.90 & 4.70 & 0.11 & 0.49 & 0.003 & 0.17 \\
\hline Drying-off BW, kg & 548.0 & 510.5 & 405.7 & 392.0 & 12.1 & $<0.001$ & 0.005 & 0.17 \\
\hline Drying-off BCS & 5.24 & 4.38 & 4.75 & 4.37 & 0.13 & 0.033 & $<0.001$ & 0.019 \\
\hline
\end{tabular}

${ }^{1}$ Standard error of the difference between treatment means.

${ }^{2} \mathrm{BCS}$ on a 1- to-10 scale (Roche et al., 2004).

The shorter lactation length for once-daily compared with twice-daily cows in 2000-2001 and 2001-2002 was associated with summer droughts that reduced growth rates and quality of pastures. Cows were dried off because of poor milk yield and high SCC, despite the fact that BCS was above the threshold for drying off, based on farm-system decision rules. In contrast, 2001-2002 and 2003-2004 had good summer rainfall allowing high pasture growth rates. During these years, lactation lengths were the same for once-daily and twice-daily cows and milk and MS per ha yields were greater. Rémond et al. (2004) recorded lactation lengths of 305 and $293 \mathrm{~d}$ for cows milked twice daily and once daily, respectively, because more of the once-daily cows fell below the drying off criterion of $<6 \mathrm{~kg}$ of milk/d.

\section{Milk Composition}

Davis et al. (1999) reviewed changes in milk composition during once-daily milking. Fat content increases of 0.10 to $0.35 \mathrm{~g} / \mathrm{kg}$, protein content increases of 0.14 to $0.21 \mathrm{~g} / \mathrm{kg}$, and lactose content decreases of 0.08 to $0.23 \mathrm{~g} / \mathrm{kg}$ occurred with once-daily milking. Davis et al. (1999) considered that many of the changes in milk composition were caused by changes in permeability of tight junctions between the secretory epithelial cells leading to increased exchange of milk and interstitial fluid (Stelwagen et al., 1994). The current study and others (Claesson et al., 1959; Holmes et al., 1992; Rémond et al., 2004) show consistent trends in milk compositional changes with once-daily milking averaged during the entire lactation.

Our results showed that both breeds had consistently elevated SCC on once-daily compared with twice-daily milking throughout lactation in all years. These elevations occurred despite no difference in the number of clinical or subclinical infections between once-daily and twice-daily milked cows (Lacy-Hulbert et al., 2005.). In a New Zealand commercial herd milked once daily for $20 \mathrm{yr}$, Harding et al. (2002) reported that $7 \%$ of the herd was culled each year because of high SCC, and from 1996-2002, annual average bulk milk SCC was 150,000 to 170,00 cells/mL. Kamote et al., (1994) suggested that the increased SCC during once-daily milking could be accounted for by a concentration effect, whereby the number of somatic cells secreted into milk was constant, but the volume of milk decreased. Stelwagen and Lacy-Hulbert (1996) showed, however, that an

Table 6. Use of controlled internal drug release insert (CIDR), 3-and 6-wk AI submission rates, 3- and 6wk conception rates, 3- and 6-wk pregnancy rates, time of first estrus and conception, planned start of breeding (PSB) to conception, calving to conception, and total number of inseminations for Holstein-Friesian $(\mathrm{HF})$ and Jersey $(\mathrm{J})$ cows milked once $(1 \times)$ or twice $(2 \times)$ daily (4-yr average)

\begin{tabular}{|c|c|c|c|c|c|c|c|c|}
\hline & \multicolumn{4}{|c|}{ Breed-daily milking frequency } & \multirow[b]{2}{*}{$\mathrm{SED}^{1}$} & \multicolumn{3}{|c|}{$P$-value } \\
\hline & $\mathrm{HF}-1 \times$ & $\mathrm{HF}-2 \times$ & $\mathrm{J}-1 \times$ & $\mathrm{J}-2 \times$ & & Breed & Frequency & Interaction \\
\hline Use of CIDR, \% & 5.2 & 23.7 & 5.9 & 9.4 & 3.4 & 0.019 & 0.001 & 0.012 \\
\hline 3 -wk submission rate, \% & 89.7 & 79.3 & 94.4 & 90.1 & 3.2 & 0.008 & 0.01 & 0.22 \\
\hline 6-wk submission rate, $\%$ & 98.6 & 94.9 & 98.8 & 98.6 & 2.6 & 0.32 & 0.32 & 0.37 \\
\hline 3-wk conception rate, \% & 46.5 & 47.3 & 53.6 & 44.1 & 5.9 & 0.65 & 0.32 & 0.25 \\
\hline 6 -wk conception rate, \% & 70.9 & 70.9 & 76.0 & 68.6 & 4.6 & 0.67 & 0.27 & 0.28 \\
\hline 3 -wk pregnancy rate, $\%$ & 41.8 & 37.4 & 50.4 & 39.3 & 5.0 & 0.17 & 0.055 & 0.37 \\
\hline 6 -wk pregnancy rate, $\%$ & 69.8 & 67.3 & 75.1 & 67.6 & 4.3 & 0.38 & 0.13 & 0.44 \\
\hline Calving to first estrus, $\mathrm{d}$ & 51.3 & 53.6 & 49.9 & 49.6 & 3.8 & 0.36 & 0.74 & 0.63 \\
\hline PSB to conception, $\mathrm{d}$ & 26.1 & 28.2 & 23.8 & 28.4 & 1.60 & 0.38 & 0.016 & 0.30 \\
\hline Calving to conception, $\mathrm{d}$ & 84.5 & 87.8 & 84.6 & 91.6 & 2.88 & 0.36 & 0.034 & 0.39 \\
\hline No. of inseminations/cow & 1.73 & 1.72 & 1.68 & 1.71 & 0.1 & 0.68 & 0.92 & 0.78 \\
\hline
\end{tabular}

${ }^{1}$ Standard error of the difference between treatment means. 
increase in SCC during once-daily milking coincided with an increase in neutrophil numbers. Research indicates that once-daily milking did not increase the incidence of clinical mastitis and that SCC concentrations can be controlled under once-daily milking when udders are free from bacterial infection and SCC are small at the start of lactation (Lacy-Hulbert et al., 2005).

Holmes et al. (1992) reported an increase in SCC with once-daily milking, but in 2 short-term studies, oncedaily milking did not increase SCC (Stelwagen et al., 1994; Lacy-Hulbert et al., 1995). Kamote et al. (1994) observed that cows with high SCC ( $>800,000$ cells $/ \mathrm{mL}$ ) at the start of once-daily milking were more likely to show an increase during once-daily milking than those with low SCC $(150,000$ cells $/ \mathrm{mL})$. This is supported by Rémond et al. (2004) who reported no difference in mean SCC during an entire lactation for cows milked either once daily or twice daily, although a more rapid increase did occur for once-daily cows during the last third of lactation.

\section{Parity}

The current results show a trend for HolsteinFriesian 2- and 3-yr-old cows to be less tolerant of oncedaily milking than Jerseys of all ages or older HolsteinFriesians. Further work with greater numbers of cows is required before firm recommendations can be made regarding age selection of Holstein-Friesians suitable for once-daily milking. Two-year-old Holstein-Friesians gained large amounts of BW during their first year on the experiment and it is possible that energy was used for growth rather than milk production during this period. Rémond et al. (1999) reported no difference in the effect of once-daily milking for $3 \mathrm{wk}$ for cows of different parities, but Claesson et al. (1959) showed a greater effect for primiparous cows. Rémond and Boit (1997) showed a greater effect of milking 3 times in $2 \mathrm{~d}$ on primiparous cows in early, but not in late, lactation for 3 -wk trials. In contrast, Woolford et al. (1985) showed that primiparous cows yielded $18 \%$ less and multiparous cows $7 \%$ less during an entire lactation. Firstlactation cows may not be able to accommodate the increased milk storage under once-daily milking, because they tend to have smaller cisterns than mature cows. Furthermore, some studies have shown an inverse correlation between cisternal milk volume and milk yield loss under once-daily milking (Knight and Dewhurst, 1994; Stelwagen and Knight, 1997), but this relationship was not as strong in other trials (Carruthers et al., 1993). Overall, these results indicate that any effect of once-daily milking is likely to be greater in primiparous cows, especially when they are milked once daily during an entire lactation, despite many of the differences not being statistically tested in the previously cited reports.

\section{$B W$ and $B C S$}

There is general agreement that cows milked on a 16- or 24-h interval lose less BW and condition during early lactation, or gain more BW and condition during midlactation than those milked twice daily (Woolford et al., 1985; Lynch et al., 1991; Holmes et al., 1992; Rémond et al., 2004). In the current study, milking frequency had no effect on postcalving BW in most years; however, cows on all treatments gained weight during each lactation. Averaged for all $4 \mathrm{yr}$, twice-daily Holstein-Friesians, once-daily Jerseys, and twice-daily Jerseys put on 43,44 , and $50 \mathrm{~kg}$ of BW, respectively, whereas BW in the once-daily Holstein-Friesians increased by $94 \mathrm{~kg}$. This implies that more DMI was being partitioned to BW gain in the once-daily HolsteinFriesians than in the other treatment combinations, and that the stocking rate for once-daily HolsteinFriesians could have been increased further. This would only lead to an increased MS per ha, however, if a greater proportion of DMI were directed to milk rather than to BW gain. Greater stocking rates also create greater discrepancies between pasture supply and feed demand, and increase the variable costs associated with once-daily milking. A better strategy would be to select, and eventually breed, once-daily tolerant cows with greater lactation persistence.

\section{Reproduction}

Our results confirmed observations on commercial New Zealand farms that cows milked once daily have improved 3-wk AI submission rates, and substantiated farmer predictions that once-daily milking would reduce use of CIDR inserts, because fewer cows would be anestrus at planned start of breeding. Although milking frequency did not influence final pregnancy rates, oncedaily milking reduced the time from calving to conception by $5 \mathrm{~d}$. This reduced the number of cows culled because of late calving and reduced the need for induced calving to maintain a 365-d calving cycle. These issues are less important for nonseasonal calving herds, but in spring-calving New Zealand herds, reduced calving intervals will have a positive effect on profitability and the welfare and longevity of individual cows. Small numbers of cows were involved in this study and an accurate assessment of the effect of milking frequency on reproductive performance must await studies with much larger numbers of cows.

Little research is available comparing reproductive performance under once-daily and twice-daily milking 
during entire lactations. Rémond et al. (2004) reported an increased pregnancy rate at $102 \mathrm{~d}$ postcalving for once-daily compared with twice-daily milked cows (89 vs. 57\%, respectively). Rhodes et al. (1998), working with commercial New Zealand dairy farms, observed that a 4-wk period of once-daily milking around planned start of breeding increased the spontaneous resumption of estrus cycles in anestrous cows compared with twicedaily milking, but did not increase conception rates to first insemination.

\section{CONCLUSIONS}

Milk, protein, fat, and lactose yields from Jersey cows were less affected by once-daily milking than those from Holstein-Friesians in a pasture-based New Zealand dairy system. Cows of all ages in both breeds can be successfully milked once daily with no long-term consequences when once-daily milking occurs for multiple lactations. Milking once daily improved BW and BCS at dry-off, reduced use of CIDR inserts, and days to conception. Further, it increased milk protein content and SCC, but decreased lactose content, and led to shorter lactations compared with twice-daily milking. Milking once daily is a viable milking option for New Zealand farmers who are prepared to trade-off loss of farm MS income for increased time available for nonmilking activities. Viability of once-daily milking could be improved substantially by selecting cows that are tolerant of once-daily milking, assuming this trait is heritable.

\section{ACKNOWLEDGMENTS}

We thank Brian Walsh, Steven Blakely, Kelly Andrews, and John Siemelink for management of the experimental herds and pastures; Chris Roach and Lynette Maulder for technical assistance; Brendan Attrill for research station management and valuable discussions; Dexcel Milk Laboratory for milk analyses; Jane Lacy-Hulbert and John Williamson for udder bacteriology and advice on SCC issues; Gwyn Verkerk for herd reproductive management; Michael Joyce (Farmwise, Livestock Improvement Corporation) for feed budgeting and farm management advice; and Barbara Dow, with assistance from Marie-Lynn Posnic, for statistical analyses. New Zealand Dairy Board Global Research Fund (project number R1491) and Dairy InSight (project number 10078) funded the research.

\section{REFERENCES}

Attrill, B., and C. W. Holmes. 1993. Once-daily milking throughout lactation in a commercial herd. Massey University Dairy Farming Annu. 45:181-182.
Bryant, A. M. 1978. Once-a-day milking: Effects on production, live weight and grazing. AgLink, Farm Production and Practice No. 158, Media Services, MAF, Wellington, New Zealand.

Carruthers, V. R., and P. J. A. Copeman. 1990. Once a day milking: What are the effects on productivity? Massey University Dairy Farmers Annu. 42:75-78.

Carruthers, V. R., S. R. Davis, A. M. Bryant, H. V. Henderson, C. A. Morris, and P. J. A. Copeman. 1993. Response of Jersey and Friesian cows to once a day milking and prediction of response based on udder characteristics and milk composition. J. Dairy Res. 60:1-11.

Claesson, O., A. Hansson, N. Gustafsson, and E. Brannang. 1959. Studies on monozygous cattle twins. XVII. Once-a-day milking compared with twice-a-day milking. Acta Agric. Scand. 9:38-58.

Davis, S. R., V. C. Farr, and K. Stelwagen. 1998. Once daily milking of dairy cows: An appraisal. Proc. N.Z. Soc. Anim. Prod. 58:36-40.

Davis, S. R., V. C. Farr, and K. Stelwagen. 1999. Regulation of yield loss and milk composition during once-daily milking: A review. Livest. Prod. Sci. 59:77-94.

Harding, L., G. Harding, F. Harding, and R. Harding. 2002. Milking cows once daily since 1985: Our reasons and experience. Massey University Dairy Farming Annu. 54:85-87.

Holmes, C. W., G. F. Wilson, D. D. S. Mackenzie, and J. Purchas. 1992. The effects of milking once daily throughout lactation on performance of cows grazing pasture. Proc. N.Z. Soc. Anim. Prod. $52: 13-16$.

Kamote, H. I., C. W. Holmes, D. D. S. Mackenzie, R. J. Holdaway, and B. W. Wickham. 1994. Effects of once-daily milking in later lactation on cows with either low or high initial somatic cell counts. Proc. N.Z. Soc. Anim. Prod. 54:285-287.

Knight, C. H., and R. J. Dewhurst. 1994. Once daily milking of dairy cows: Relationship between yield loss and cisternal milk storage. J. Dairy Sci. 61:441-449.

Lacy-Hulbert, S. J., D. E. Dalley, and D. A. Clark. 2005. The effects of once-daily milking on mastitis and somatic cell count. Proc. N.Z. Soc. Anim. Prod. 65:137-142.

Lacy-Hulbert, S. J., M. W. Woolford, and A. M. Bryant. 1995. Influence of once-daily milking and restricted feeding on milk characteristics in late lactation. Proc. N.Z. Soc. Anim. Prod. 55:85-87.

Lynch, G. A., M. E. Hunt, and D. D. S. Mackenzie. 1991. The effects of once-daily milking as a management practice in late lactation. Proc. N.Z. Soc. Anim. Prod. 51:191-195.

Macdonald, K. A., and J. W. Penno. 1998. Management decision rules to optimise milk solids production on dairy farms. Proc. N.Z. Soc. Anim. Prod. 58:132-135.

Mackenzie, D. D. S., G. A. Lynch, and M. E. Hunt. 1990. Once daily milking: Physiological response, costs and benefits. Massey University Dairy Farming Annu. 42:79-84.

Macmillan, K. L., V. K. Taufa, D. R. Barnes, and A. M. Day. 1991. Plasma progesterone concentrations in heifers with a new intravaginal device. Anim. Reprod. Sci. 26:25-40.

Morris, C. A., S. R. Davis, and V. R. Carruthers. 1991. Once-daily milking. Pages 120-126 in Proc. 9th Conf. Australas. Assoc. Anim. Breeding, University of Melbourne, Australia. CSIRO, Collingwood, Australia.

Parker, O. F. 1965. Milking cows once a day. Proc. Ruakura Farmers Conf. 17:236-240.

Rémond, B., and M. P. Boit. 1997. Effects of milking three times in two days for 3 weeks in early lactation or in the declining phase on milk production in primiparous or multiparous dairy cows. Ann. Zootech. 46:339-348.

Rémond, B., J.-B. Coulon, M. Nicloux, and D. Levieux. 1999. Effect of once-daily milking in early lactation on milk production and nutritional status of dairy cows. Ann. Zootech. 48:341-352.

Rémond, B., D. Pomiès, D. Dupont, and Y. Chilliard. 2004. Once-aday milking of multiparous Holstein cows throughout the entire lactation: Milk yield and composition, and nutritional status. Anim. Res. 53:201-212.

Rhodes, F. M., B. A. Clark, K. L. Macmillan, and S. McDougall. 1998. Use of once-daily milking or treatment with progesterone and oestradiol benzoate in anoestrus cows. Proc. N.Z. Soc. Anim. Prod. $58: 44-46$. 
Roche, J. R., P. G. Dillon, C. R. Stockdale, L. H. Baumgard, and M. J. VanBaale. 2004. Relationships among international body condition scoring systems. J. Dairy Sci. 87:3076-3079.

Stelwagen, K., S. R. Davis, V. C. Farr, S. J. Eichler, and I. Politis. 1994. Effects of once-daily milking and concurrent somatotropin on mammary tight junction permeability and yield of cows. J. Dairy Sci. 77:2994-3001.

Stelwagen, K., and C. H. Knight. 1997. Effect of unilateral once and twice-daily milking of cows on milk yield and udder characteristics in early and late lactation. J. Dairy Res. 64:487-494.

Stelwagen, K., and S. J. Lacy-Hulbert. 1996. Effect of milking frequency on milk somatic cell characteristics and mammary secretory cell damage in cows. Am. J. Vet. Res. 57:902-905.
Wilson, G. F. 1965. Once daily milking. Massey University Dairy Farming Annu. 17:50-55.

Woolford, M. W., P. J. A. Copeman, A. R. Napper, D. S. M. Phillips, J. H. Williamson, and E. J. Uljee. 1985. Milking intervals: Are changes worthwhile? Proc. Ruakura Farmers Conf. 37:120-128.

Woolford, M. W., D. S. M. Phillips, and P. J. A. Copeman. 1982. New concepts in milking management and milking machines. Proc. Ruakura Farmers Conf. 34:97-101.

Xu, Z., and L. J. Burton. 2000. Reproductive Performance of Dairy Cows in New Zealand. Pages 23-41 in Proc. Aust. and N.Z. Combined Dairy Veterinarians' Conf. Vet. Contin. Educ., Massey Univ., Palmerston North, New Zealand. 